\title{
Differences in cytotoxicity between $5 \%$ tetracycline hydrochloride and $15 \%$ EDTA as root canal irrigant
}

Devi Eka Juniarti, Karlina Samadi, and Achmad Sudirman

Department of Conservative Dentistry

Faculty of Dentistry, Airlangga University

Surabaya - Indonesia

\begin{abstract}
$5 \%$ tetracycline hydrochloride and 15\% EDTA as a root canal irrigant have been proven to be able to remove smear layer, open dentinal tubules and have antimicrobial activity. An effective root canal irrigation solution must be able to dissolve organic and anorganic debris, lubricate endodontic instruments, disinfect microorganism and non toxic. The purpose of this laboratory experimental study was to determine cytotoxicity differences between 5\% tetracycline hydrochloride and 15\% EDTA. 21 samples were used and classified into 3 groups: control, $5 \%$ tetracycline hydrochloride and $15 \%$ EDTA groups. Cytotoxicity test was done using BHK ${ }_{21}$ cells. The data was analyzed using Bird and Forrester formula. It concluded that 5\% tetracycline hydrochloride more toxic than $15 \%$ EDTA as a root canal irrigant.
\end{abstract}

Key words: cytotoxicity, 5\% tetracycline hydrochloride, 15\% EDTA, fibroblast

Correspondence: Devi Eka Juniarti, c/o: Departemen Konservasi Gigi, Fakultas Kedokteran Gigi Universitas Airlangga. Jln. Mayjend. Prof. Dr. Moestopo no. 47 Surabaya 60132, Indonesia.

\section{INTRODUCTION}

Washing and forming root canal, though, other aspects could not be ignored. During the washing and forming rot canal should be followed by irrigation to remove fragment of pulp tissue and accumulation of dentinal fragment. ${ }^{1}$ Podbeilski ${ }^{2}$ suggested that root canal preparation without root canal irrigation contributing about $70 \%$ debris left on apical region. Several active chemical substances were used for irrigation with the purpose to wash, lubricate, kill microorganism, solve the tissue and remove smear layer. $^{3}$

Smear layer on dentinal tubule might inhibit diffusion of post root canal filling on the surface of root canal. ${ }^{4,5}$ Removal of smear layer using demineralization material such as: citrate acid, EDTA and tetracycline hydrochloride solution. Demineralization material (chelating agent) would remove smear layer due to the capability of forming complex binding (chelate) with calcium content of smear layer. $^{6}$

Further study on cytotoxicity of root canal irrigant material should be done to find irrigant with maximal anti microbial effect and capability to remove smear layer with minimal toxic effect. Citrate acid $30 \%$ could be used as root canal irrigant material which has the capability as chelating agent but it would contribute color change (brownish/ burned like color) if it affects soft tissue. ${ }^{7}$

EDTA is know as most effective chelating agent in root canal treatment. ${ }^{8}$ EDTA has the capability to solve dentin, to remove smear layer, relative nontoxic effect as well as light irritation. ${ }^{1}$ EDTA has natrium saline content, which could solve calcium in $15 \%$ concentration. ${ }^{9}$
The previous study on cytotoxicity comparison between $0.2 \%$ EDTA as washing material of tooth cavity and $1 \%$ benzalconium chloride, the result suggested $0.2 \%$ EDTA 9-10\% had higher toxicity comparing to $1 \%$ benzalconium chloride. ${ }^{10}$ Ogundele ${ }^{11}$ had done in vitro study on EDTA cytotoxicity using human cell damaged cells taken from breast milk and the result suggested the presence of damaged cells in breast milk cells with EDTA and the absence of damaged cells without EDTA. The an other study on Baby Hamster's Kidney given EDTA showed vacuolization and degeneration of proximal tubule cells. ${ }^{12}$

Another root canal irrigant material which has the capability as chelating agent is tetracycline hydrochloride. In in vitro study using tetracycline hydrochloride could remove smear layer, release debris and open dentinal tubule. The result was better comparing to aquadest irrigant, sodium hypochlorite and citrate acid. ${ }^{13}$ Irrigation using tetra cycline hydrochloride $5-15 \%$ shows it could effectively remove smear layer and significantly open dentinal tubule. ?,14,15 $^{7}$ Meanwhile there is no significant difference found in anti bacterial capability of 5-15\% tetracycline hydrocloride. ${ }^{15}$

Cytoxicity study suggested that all cells died after being given $10 \%$ tetracycline hydrochloride while the mean of live cells was $0.25 \%$ after being given $7.5 \%$ tetracycline hydrochloride.

Fifteen percent EDTA has capability to solve calcium, ${ }^{9}$ therefore smear layer is effectively washed and would soften. The dentin in obstructive root canal treatment. Five percentage tetracycline hydrochloride have been proved to be able to wash smear layer, to open dentinal tubule as well as to have anti bacterial capability. ${ }^{15,16}$ 
Both $15 \%$ EDTA and 5\% tetracycline hydrochloride have proved to have effectively in washing smear layer and binding calcium dentin in the treatment of root canal, however, difference of toxicity between both of them as irrigant material toward fibroblast tissue still requires further study. The purpose of the study is to know the difference of toxicity in $15 \%$ EDTA with $5 \%$ tetracycline hydrochloride.

\section{MATERIALS AND METHODS}

The sample of study was fibroblast cell (Baby Hamster kidney-21) and the free variables were 5\% tetracycline hydrochloride p.a. and 15\% EDTA p.a., dependent variables was the number of alive and death fibroblast cells: control variables were temperature $37^{\circ} \mathrm{C}$, volume, contact time between irrigant and fibroblast cells, tool sterility, the amount of irrigant, media, the number of fibroblast cells, time cell culture incubation. The study was performed at PUSVETMA, Jl A. Yani, Surabaya.

The material which were used in the study were sterile aquadest, $5 \%$ tetracycline hydrochloride p.a., 15\% EDTA p.a, $\mathrm{BHK}_{2}, 54$ cell culture papase, $10 \%$ bovine serum, phosphat buffer saline, $0.25 \%$ trypsine versene, tryphan blue, eagle media. The tools which were used: petrdish diameter $5 \mathrm{~cm}$, micropipet, laminar flow, light microscope, incubator, hemositometer, culture bottle (roux), balance.

Firstly, 5\% tetracycline hydrochloride was made, weighing $5 \%$ tetracycline hydrochloride mixed with aquadest $100 \mathrm{ml}$, secondary 15\% EDTA was made, weighing $17 \mathrm{gr}$ pure natrium powder dinatrium EDTA. Solved in 9,25 $\mathrm{ml} \mathrm{NaOH}$ and $100 \mathrm{ml}$ sterile aquadest. Sample preparation using fibroblast cell (BHK-21) kept in sustaining media containing $10 \%$ dimethyl Sulfoxid (DMSO) $+90 \%$ bovine serum, in freezing condition $\left(-85^{0} \mathrm{C}\right)$. Revival of fibroblast cell BHK-21, was done (Revivaling freezing BHK-21 fibroblast cell) before the study was started, by placing into the incubator $\left(37^{\circ} \mathrm{C}\right)$ for 10 minutes until media melted. Melting BHK-21 fibroblast was balanced by adding some water, after the balance was obtained, BHK-21 fibroblast cell was put into centrifuge and was stirred for 10 minutes at speed $200 \mathrm{rpm}$.

Saving media of precipitation of fibroblast cell (BHK-21) was disposed and replaced by new growing media consisted of eagle $+10 \%$ bovine serum.

BHK-21 fibroblast cells which was in the new growth media (media eagle $+10 \%$ bovine serum) were put into roux bottle and kept into incubator $\left(37^{\circ} \mathrm{C}\right)(2 \times 24$ hour $)$ until the cells completely grew (confluent $20 \times 10^{5} \mathrm{cell} / \mathrm{ml}$ ). Roux bottle which was fully filled with BHK-21 fibroblast cell $(100 \%)$ then washed twice using PBS followed by trypsination in $0,25 \%$ trypsin versene added by new eagle media, next it was classified into 4 bottles with initial confluent $5 \times 10^{5}$ cell $/ \mathrm{ml}$, put into incubator $37^{\circ} \mathrm{C}$ ( 48 hour $)$ until cell confluent would reach $210^{5}$ cell $/ \mathrm{ml}$. This process was called $55^{\text {th }}$ papase. In order to separate into individual cell which were initially cluster, therefore they should be placed on petridish. the making of BHK-21 fibroblast cell on the petridish required 21 petridish which were divided in 3 groups in which each group consisted of 7 samples. BHK-21 fibroblast cell mono layer fibroblast cell was left to contact $15 \%$ tetracycline hydrochloride and 15\% EDTA for 3 minutes in which it was done according to control group, then, the irrigant was disposed an trypsination was repeated similarity to previously done. 21 samples were used in this study and divided into 3 control groups in which each group consisted of 7 samples.

Three minutes after fibroblast cell (BHK-21) processing was done in petridish, $0,1 \mathrm{cc}$ of cell suspension was taken and added by $0,9 \mathrm{cc}$ tryphan blue, stirred by spraying and sucking 3 times by pipet until the cell was homogeneous, when homogeneous condition was obtained than $0.1 \mathrm{cc}$ was taken and dropped into hemocytometer and soon the calculation was done through light microscope, finally Bird and Forrester ${ }^{16}$ equation was applied:

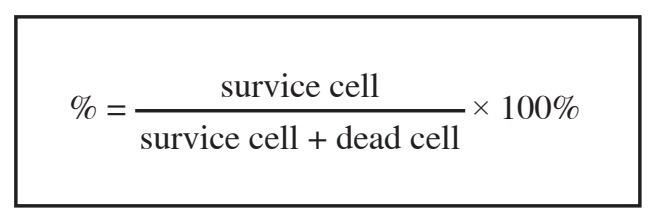

The higher the percentage of survival cells (clear), the lower the percentage dead cells (dark), so the toxicity was lower meaning the test material would more bio compatible. To compare the mean among the groups on toxicity test of 5\% tetracycline hydrochloride and $15 \%$ EDTA, independent t-Test was done.

\section{RESULT}

The result of the study on difference of cytotocity between 5\% tetracycline hydrochloride and 15\% EDTA has been shown on table 1 . Before the best for different percentage of alive fibroblast cell among control groups was done, in every control group, data distribution test was done for the percentage of alive cells, Kolmogorov Smirnov test was used for variant homogeneity and levene test was for statistical test. The result of data distribution test shows in all control groups the percentage of alive fibroblast cell has normal data distribution ( $\mathrm{p}>0.05)$. Independent t-Test is done to know the difference of percentage of survive fibroblast cells among control groups. I have been shown on table 2 .

Table 1. The mean percentage of alive fibroblast cells

\begin{tabular}{lccc}
\hline & $\mathrm{N}$ & $\overline{\mathrm{X}}$ & $\mathrm{SD}$ \\
\hline Control & 7 & 95,9671 & 1,1581 \\
15\% EDTA & 7 & 80,5371 & 8,6092 \\
Tetracycline $\mathrm{HCl}$ & 7 & 17,8186 & 6,3769 \\
\hline
\end{tabular}

Note: N: The number of samples; SD: Standard Deviation; $\overline{\mathrm{X}}$ : Mean $(\%)$ 
Table 2. $\mathrm{p}$ value of independent t-Test on percentage of survive fibroblast cell among group control, $15 \%$ EDTA and 5\% tetracycline $\mathrm{HCl}$

\begin{tabular}{lccc}
\hline & Control & $15 \%$ & $5 \%$ Tetracycline \\
& EDTA & HCl \\
\hline Control & $\mathrm{p}=0.003$ & $\mathrm{p}=0.001$ \\
$15 \%$ EDTA & & $\mathrm{p}=0.001$ \\
$5 \%$ Tetracycline & & \\
\hline
\end{tabular}

On the table 2 has been shown the test result of difference among all groups measuring the percentage of survive fibroblast cell (control, 15\% EDTA, 5\% tetracycline $\mathrm{HCl}$ ) with $\mathrm{p}<0.05$. It is shows there is significant difference among 3 groups measuring the percentage of survive.

\section{DISCUSSION}

In high concentration, tetracycline could inhibit not only synthesis of bacterial protein but also mammalian cell protein. ${ }^{7,16}$ Tetracycline is capable to diffuse passively through hydrophilic pores in outer part of cell membrane and through active transport passed inner part cell membrane and bind ribosome sub unit. This binding would inhibit the entry of t-Rna and amino acid in peptide chain elongation process therefore protein synthesis is inhibited. Tetracycline also tends to irritate tissue due to strong acid nature. ${ }^{16,17}$ $15 \%$ EDTA would influence fibroblast cell metabolism through chelating effect i.e to have complex binding with ion of inorganic cell and outer surface of plasma of cell membrane so structure disturbance and permeability of cell membrane would occur. ${ }^{10,18}$ Based on the previous study that $15 \%$ EDTA was less toxic due to chelating agent mechanism with limited reaction on calcified tissue and periapical tissue was not significantly influenced, in addition EDTA also has netral pH: 7.5 therefore tissue irritation will not occur. ${ }^{19,20}$

Cytotoxicity test was done using cell culture method with the advantage of having more accurate result, quantitative toxicity measurement could be achieved and cell response could be observed. ${ }^{21}$ It is conclude that $5 \%$ tetracycline hydrochloride has higher toxicity comparing to $15 \%$ EDTA.

\section{REFERENCES}

1. Grossman LL, Olliet S, Del Rio CE. Ilmu endodontik dalam praktek. Abyono R, editor. Edisi ke-11. Jakarta: EGC; 1995. p. 47-8, 59, 205-11.
2. Podbielski A, Bolckh C, Haller. Growth inhibitory activity of gutta percha points containing root canal medications on common endodontic bacterial pathologenis as determined by an optimized quantitative in vitro assay. J Endodon 2000; 7:398-403.

3. Cohen SC, Burns RC. Pathways of the pulp. $7^{\text {th }}$ ed. St. Louis: CV Mosby Co; 1998. p. 206-7.

4. Torabinejad M, Khademi AA, Babagoli J, Cho Y, Johnson WB, Bozhilov K. A new solution for the removal of the smear layer. J Endodon 2003; 29(3):170-5.

5. Foster KH, Kulild JC, Weller N. Effect of smear layer removal on the diffusion of calcium hydroxide through radicular dentin. J Endodon 1994; $2: 78$.

6. Maduratna E. Kebersihan permukaan dentin akar setelah pemberian larutan tetrasiklin hidroklorida disbanding asam sitrat. Penelitian Dosen Muda. Surabaya: Universitas Airlangga; 1998. p. 9-10.

7. Maduratna E. Terlepasnya lapisan smir pada permukaan akar setelah pemberian larutan tetrasiklin hidroklorida. Majalah Kedokteran Gigi (Dental Journal) 2000; 33(3):106-8.

8. Serper A, Calt S. The demineralizing effects of EDTA at different concentrations and pH. J Endodon 2002; 28(7):501-2.

9. Utami LM. Perbedaan larutan EDTA $15 \%$ dan EDTAC $15 \%$ dalam menghilangkan smear layer pada dinding saluran akar. Skripsi. Surabaya: Fakultas Kedokteran Gigi Universitas Airlangga; 1998. p. 40 .

10. Subiyanto A. Pengaruh pemakaian bahan EDTA $0,2 \%$ dan benzalkonium klorid $1 \%$ sebagai pembersih kavitas gigi terhadap kultur jaringan hidup. Penelitian Dosen Muda. Surabaya: Universitas Airlangga; 1996. p. 13-5.

11. Ogundele M. Cytotoxicity of EDTA used in biological samples: Effect on some breastmilk studies. 2003. p. 1-9. Available at: http://www. medfive.com/edta. Accessed 2006.

12. Kunardi L, Setiabudi R. Farmakologi dan terapi. Jakarta: Bagian Farmakologi Fakultas Kedokteran, Universitas Indonesia; 1995. p. 651-60, 794-5.

13. Haznedaroglu, Ersev $\mathrm{H}$. Tetracycline $\mathrm{HCl}$ solution as a root canal irrigant. J Endodon 2001; 27(12):738-40.

14. Isik AG, Tarim B, Hafez AA, Yalcin FS, Onan U, Cox CF. A comparative scanning electron microscope study on the characteristic of demineralized dentin root surface using different tetracycline $\mathrm{HCl}$ concentrations and application times. J Periodontal 2000; 71(2):219-25.

15. Rostyarini S. Daya hambat mikroorganisme menggunakan larutan tetrasiklin $\mathrm{HCl}$ 5\%, 10\%, 15\% sebagai bahan irigasi pada perawatan saluran akar. Karya Tulis Akhir. Surabaya: Universitas Airlangga 2005. p. 33.

16. Maduratna E. Sitotoksisitas larutan tetrasiklin hidroklorida terhadap kultur sel dibanding asam sitrat. Majalah Kedokteran Gigi (Dental Journal) 2002; 35(4):164-6.

17. Rianto S. Farmakologi dan terapi. Edisi ke-4. Jakarta: Bagian Farmakologi Fakultas Kedokteran Universitas Indonesia; 2003. p. 651-60, 794-5.

18. Ogundele M. The role of divalent cations in the mechanism of EDTA cytotoxity. http://F: INABIS`98 2006. p. 1.

19. Maduratna E. Biokompatibilitas gel tetrasiklin hidroklorida terhadap kultur jaringan. Majalah Kedokteran Gigi (Dental Journal) 1999; 32(4):140-3.

20. Canderasari NM. Perbedaan sitotoksisitas larutan tetrasiklin hidroklorida $1 \%$ dengan natrium hipoklorit 2,5\%. Karya Tulis Akhir. Surabaya: Universitas Airlangga; 2004. p. 1.

21. Walton RE, Torabinejad M. Prinsip dan ilmu praktek ilmu endodonsi. Edisi ke-2. Jakarta: EGC; 1997. p. 360-78. 